\title{
Motor development's curves of premature infants on the first year of life according to Alberta Infant Motor Scale
}

\author{
Curvas de desenvolvimento motor de crianças prematuras no \\ primeiro ano de vida segundo a Alberta Infant Motor Scale
}

\section{Curvas de desarrollo motor de niños prematuros en el primer año de vida según la Alberta Infant Motor Scale}

\section{Raquel Saccani ${ }^{[a]}$, Nadia Cristina Valentini ${ }^{[b]}$, Keila Ruttnig Guidony Pereira ${ }^{[b]}$, Cibelle Kayenne Martins Roberto Formiga ${ }^{[\mathrm{c}]}$, Maria Beatriz Martins Linhares ${ }^{[\mathrm{d}]^{*}}$}

[a] Universidade de Caxias do Sul (UCS), Caxias do Sul, RS, Brazil

[b] Universidade Federal do Rio Grande do Sul (UFRGS), Porto Alegre, RS, Brazil

[c] Universidade Estadual de Goiás (UEG), Goiânia, GO, Brazil

[d] Universidade de São Paulo (USP), Ribeirão Preto, SP, Brazil

Abstract

Introduction: The motor trajectory of pre-term children is an important indicator of health during infancy, since alterations may be a signal for the need of professional intervention. Objective: To describe percentiles and motor development curves for Brazilian preterm infants in the first year of life, determining the reference values for categorization of motor performance assessed by the AIMS. Methods: Participated in this cross-sectional study 976 children born pre-term, newly-born to 12

*RS : PhD, email: raquelsaccani@yahoo.com.br NCV: PhD, email: nadia.cristina@ufrgs.br KRGP: Doctoral Student, email: keilargpereira@gmail.com CKMRF: PhD, email: cibellekayenne@gmail.com MBML: PhD, email: linhares@fmrp.usp.br 
months of corrected age. The Alberta Infant Motor Scale (AIMS) was used to assess participants' motor development. The scores of the Brazilian norms were used as comparison criteria. Results: Children born pre-term showed lower scores compared to children born full-term indicating the need for a specific percentile curve for that population. The scores differentiated at P1 to P99 percentiles allowing for the categorization of children with typical development, at risk and with atypical development. At $0,4,8,9,10,11$ and 12 months an overlapping of extreme percentiles (P1, P5 and P10; P90, P95 and P99) was observed, but not in the other percentiles. Conclusion: The percentiles described indicate that preterm children presented lower motor performance than full-term children and AIMS has discriminant power for the clinical evaluation of these children. The developmental curves showed lower capacity for behavioral differentiation in the extreme percentiles.

Keywords: Assessment. Motor Skills. Infant Development.

\section{Resumo}

Introdução: A trajetória motora de uma criança nascida pré-termo é um importante indicador de saúde infantil, uma vez que alterações podem ser um alerta da necessidade de intervenção profissional. Objetivo: Descrever os percentis e as curvas do desenvolvimento motor para prematuros brasileiros no primeiro ano de idade, determinando os valores de referência para categorização do desempenho motor avaliado pela AIMS. Métodos: Estudo transversal no qual participaram 976 crianças prematuras, recém-nascidos até 12 meses de idade corrigida. A Alberta Infant Motor Scale (AIMS) foi utilizada na avaliação do desenvolvimento motor dos participantes. Os escores normativos da AIMS no Brasil foram utilizados como critério de comparação. Resultados: Crianças prematuras demonstraram escores mais baixos do que crianças nascidas a termo, indicando a necessidade das curvas de percentil específicas para esta população. Os escores se diferenciaram nos percentis P1 a P99, permitindo a categorização de crianças típicas, suspeitas e atípicas. Aos 0, 4, 8, 9, 10, 11 e 12 meses de idade, observou-se sobreposição nos percentis extremos (P1, P5 e P10; P90, P95 e P99) mas não nos demais percentis. Conclusão: Os percentis descritos indicam que os prematuros apresentaram desempenho motor inferior a crianças a termo e a AIMS possui poder discriminante para avaliação clínica destas crianças. As curvas de desenvolvimento demonstraram menor capacidade de diferenciação comportamental nos percentis extremos.

Palavras-chave: Avaliação. Habilidades Motoras. Desenvolvimento Infantil.

\section{Resumen}

Introducción: La trayectoria motora de niños nacidos prematuros es un importante indicador de salud infantil, ya que los cambios pueden ser una alerta de la necesidad de intervención profesional. objetivo: Describir los percentiles y las curvas del desarrollo motor para prematuros brasileños en el primer año de edad, determinando los valores de referencia para categorización del desempeño motor evaluado por la AIMS. Métodos: Estudio transversal en el que participaron 976 niños prematuros, recién nacidos hasta 12 meses de edad corregida. La Alberta Infant Motor Scale (AIMS) fue utilizada en la evaluación del desarrollo motor de los participantes. Los escores normativos de la AIMS en Brasil se utilizaron como criterio de comparación. Resultados: Niños prematuros mostraron escores más bajos que los niños nacidos a término, indicando la necesidad de las curvas de percentil específicas para esta población. Los escores se diferenciaron en los percentiles P1 a P99, permitiendo la categorización de niños típicos, sospechosos y atípicos. A los 0, 4, 8, 9, 10, 11 y 12 meses de edad, se observó superposición en los percentiles extremos (P1, P5 y P10, P90, P95 y P99), pero no en los demás percentiles. Conclusión: Los porcentajes descritos indican que los prematuros presentaron desempeño motor inferior a niños a término y la AIMS 
posee poder discriminante para la evaluación clínica de estos niños. Las curvas de desarrollo demostraron menor capacidad de diferenciación conductual en los percentiles extremos.

Palabras clave: Evaluación. Habilidades Motoras. Desarrollo Infantil.

\section{Introduction}

Motor development and the trajectory of postural acquisitions for children that are born preterm is the subject of much research [1-7] due to their importance as indicators of physical and mental health [8]. Therefore, motor abnormalities may be a first alert to professionals [2] and point to the need for continuous diagnostic research and compensatory services, especially for children with established risks such as prematurity [2].

When compared to their at term peers, preterm children have underperformed in standardized tests; especially in the first year of age, being slower in the acquisition of motor milestones such as rolling over, sitting, crawling, standing and walking [2, 3]. Studies support the hypothesis that when prematurity is associated to low birth weight and inadequate intrauterine growth, delays are even higher [9]. Research indicates that this is due to lower brain volume and slower brain metabolism in premature infants small for the gestational age $[9,10]$ and that these findings relate to motor development [9].

The detection of motor delays or dysfunctions in the initial development is essential for preventive intervention, even if alterations diagnosed in the first year are subtle or transient and could disappear with the development of the central nervous system [11]. To provide appropriate interventional services, the use of sensitive and specific instruments that differentiate the severity level of the alterations and dysfunctions is essential $[11,12]$.

The Alberta Infant Motor Scale (AIMS) is an observational scale thatevaluates the child's spontaneous motor performance from birth to independent walking $[13,14]$. For its psychometric properties and easiness of application and interpretation, it has been used by many health professionals [7,11-24]. In clinical practice, AIMS enables the assessment of postural acquisitions by the child, identifying risk or motor delays, and indicates children who can benefit from essential intervention $[12,13]$. Therefore, AIMS has been used to predict and monitor the motor performance of children as well as intervention programs over time $[7,12,13]$.

The use of AIMS in the evaluation of children born prematurely is rising $[3-7,15,16]$, although no standardized norms exist for categorization of premature infants in Brazil and worldwide. Efforts to establish standards for AIMS's use have been directed for full-term children [18-23]. However, in Brazil, Formiga et al. [17] in describing and comparing the developmental curves of preterm infant emphasized the need to establish appropriate norms when verifying inferiority in the motor performance of preterm Brazilian children when compared to Canadian standards. The trajectory of a premature infant presents variations and may reflect serious motor issues in the medium and long term [24-26] and therefore it is necessary to establish standards for the evaluation of these children.

Moreover, as motor development is multifactorial, varying in function of socioeconomic and cultural factors $[27,28]$, there is a need to understand the normalized standards of motor performance for Brazilian children born preterm. Therefore, the present study is the first to describe the motor development percentiles and curves for Brazilian preterm infants in the first year of age, determining the reference values for categorization of motor performance assessed by AIMS.

\section{Methods}

The present study is descriptive-observational and cross-sectional. The approvals of the Research Ethics Committee of the universities of origin were obtained. The parents or legal guardians were contacted and after the signing of the informed consent term, data collection began.

Thestudy samplewas, for convenience, composed of 976 premature childrenfrom 0 to 12 months of corrected age. The inclusion criteria for preterm infants were as follows: infants with $<37$ weeks of gestational age who did notparticipate in specificinterventional programs for preterminfants. Exclusion criteria were as follows: ostheomyoarticular disorders such as fractures, diagnosed central and peripheral nerve lesions 
(obtained from hospital and pediatrician medical records), and acute diseases (viral and bacterial infections). Theinfants were born in different hospitals in three regions of Brazil, South, Southeast, and Central West.

For comparisons of the developmental curves between term and preterm infants investigated in the present study, we used the published results of the AIMS standardization study in Brazilian children [18]. The sample of said study has 1.455 Brazilian children, coming from different localities and in from diversified socioeconomic situations (children with history of perinatal problems and neurological diseases as well as those that suffered from any acute or chronic illness were excluded).

The Alberta Infant Motor Scale (AIMS) is an instrument indicated for the assessment of children's motor development from birth up to 18 months of age. The scale contains 58 items distributed into four sub-scales that describe the development of spontaneous movement and motor skills in prone $(\mathrm{n}=21)$, supine $(\mathrm{n}=9)$ ), sitting $(\mathrm{n}=12)$ and standing $(\mathrm{n}=16)$ postures. The raw score is obtained from the sum of the scores in each sub-scale and is converted into a percentile, which are used for motor performance classification. Children are observed freely without much manipulation from the examiner, focusing on aspects such as body surface that supports the weight, posture, and antigravitational movements $[14,29,30]$.

The Alberta Infant Motor Scale is a validated instrument in Brazil [29]. The results of the Brazilian validation, authorized by the authors of the original instrument, revealed: (a) content validity coefficient (CVC for clarity between 0.667 and 0.928 ; CVC for pertinence higher than 0.98); (b) high temporal stability (rho $=0.85$, $\mathrm{p}<0.001$ ); (c) high internal consistency for total score (Cronbach $\alpha=0.88$ ) and postures (Cronbach $\alpha=0.85$ to $0.89)$; (d) discriminant validity $(\mathrm{t}=-4.842, \mathrm{p}<0.001)$.

To describe the sample, a questionnaire containing characteristics of the child was used. The questionnaire contained the following items: date of birth, gender, type of delivery, weeks of gestation, APGAR at the fifth minute, birth weight, birth length, cephalic perimeter, and family monthly income.

Premature infants with 0 to 12 months of corrected age were assessed in hospitals, basic health units, at home, in public institutions, in kindergartens from the three regions in Brazil (South, Southeast and Center-West). The assessments were conducted in calm environments, in the referred locations and were filmed for further analysis, with an average duration of 20 minutes for each infant. Independent evaluators participated in the data collection, physiotherapists $(\mathrm{n}=12)$ and physical educators $(\mathrm{n}=2)$, trained in the application of the scale. During training the agreement index between the evaluators was above $80 \%$; only after the concordanceanalysis reached thislevel the data collections began. Intraclass correlation coefficients between evaluators for the data were high ( $\alpha=0.86$ to $\alpha=0.99$ ).

At the time of the evaluation, the questionnaire was given to the family or caregivers so that they could answer the questions. When necessary, the questions were clarified and information on the biological characteristics were confirmed in the child's birth card.

The data was analyzed using the Statistical Package for Social Science (SPSS, version 20.0, Chicago, IL, USA). The data demonstrated normal distribution and was analyzed using descriptive statistics, in terms of mean, standard deviation, and amplitude of variation. In addition, the AIMS gross score was expressed by percentiles $(1,5,10$, $25,50,75,90,95$ and $99 \%$ ) at each age group from birth up to 12 months of age. The analysis for gross scores, in the present study, was conducted in comparison with the Brazilian standardized scores' means reported by Saccani et al [18] using the One-Sample t-test. The level of significance adopted in the study was $\mathrm{p} \leq 0.05$.

\section{Results}

Table 1 shows the main biological and environmental characteristics of the sample. Further, $53 \%$ of the sample was female, $62 \%$ were born through cesarean delivery, and most infants (80\%) presented an APGAR index at the 5th minute between 7 and 9. In regard to maternal education, the majority of mothers (41\%) had completed high school and only $12 \%$ had attended higher education.

Table 1 - Participants' Characteristics

\begin{tabular}{lcccc}
\hline Characteristics & M & SD & Min & Max \\
\hline $\begin{array}{l}\text { Gestational Age } \\
\text { (weeks) }\end{array}$ & 32.47 & 2.34 & 20 & 36 \\
$\begin{array}{l}\text { Length at birth } \\
\text { (centimeter) }\end{array}$ & 43.29 & 4.34 & 23 & 52 \\
$\begin{array}{l}\text { Cephalic } \\
\text { perimeter } \\
\text { (centimeter) }\end{array}$ & 29.68 & 2.12 & 25 & 37 \\
$\begin{array}{l}\text { Weight at birth } \\
\text { (grams) }\end{array}$ & $1,693.19$ & 463.32 & 580 & 3,800 \\
$\begin{array}{l}\text { Length of } \\
\text { hospital stay - } \\
\text { ICU (days) }\end{array}$ & 12.86 & 20.15 & 0 & 130 \\
$\begin{array}{l}\text { Time in VM } \\
\text { (days) }\end{array}$ & 1.09 & 4.87 & 0 & 45 \\
\begin{tabular}{l} 
Income (R\$) \\
\hline
\end{tabular} & 949.52 & 568.43 & 600.00 & $3,050.00$ \\
\hline
\end{tabular}

Note: M: Mean; SD: Standard Deviation; Min: Minimum; Max: Maximum; $\mathrm{R} \$$ : reais. 
In Table 2 the differences in performance between premature and term infants can be observed. The data shows that, at the ages of 2 to 12 months, preterm infants had lower motor performance scores compared to those born at term in the Brazilian standardization study. The differences were statistically significant at most ages, with the exception of 2, 6, and 11 months. Higher motor performance scores for infants born preterm, when compared to those born at term, were observed only for newborn and 1-month-old infants.

Table 2 - AIMS gross motor performance scores by preterm and full-term children

\begin{tabular}{|c|c|c|c|c|}
\hline \multirow{2}{*}{$\begin{array}{c}\text { Age } \\
\text { Months }\end{array}$} & \multirow{2}{*}{$\begin{array}{l}\text { Pre-term } \\
\text { M (SD) }\end{array}$} & \multirow{2}{*}{$\begin{array}{l}\text { Term * } \\
\text { M (SD) }\end{array}$} & \multicolumn{2}{|c|}{$\begin{array}{c}\text { One-Sample } \\
\text { t-test \& p }\end{array}$} \\
\hline & & & t-test & $\mathrm{p}$ \\
\hline$N B<1$ & $4.94(1.71)$ & $4.3(1.20)$ & 3.90 & $<0.0001$ \\
\hline $1<2$ & 6.70 (1.76) & 5.7 (1.33) & 6.29 & $<0.001$ \\
\hline $2<3$ & 8.69 (2.09) & 8.81 (2.48) & -0.62 & 0.530 \\
\hline $3<4$ & $10.77(2.79)$ & $11.55(3.46)$ & -3.03 & 0.003 \\
\hline $4<5$ & $14.18(3.90)$ & $15.08(3.99)$ & -2.62 & 0.010 \\
\hline $5<6$ & $18.25(5.78)$ & $19.41(5.51)$ & -2.05 & 0.040 \\
\hline $6<7$ & $22.84(6.79)$ & $23.9(7.69)$ & -1.51 & 0.130 \\
\hline $7<8$ & $28.28(6.93)$ & $30.49(6.58)$ & -2.43 & 0.020 \\
\hline $8<9$ & $32.55(9.29)$ & $35.75(8.96)$ & -2.17 & 0.040 \\
\hline $9<10$ & $33.89(8.75)$ & 39.61 (8.61) & -3.45 & 0.002 \\
\hline $10<11$ & 36.95 (8.18) & $44.15(8.10)$ & -4.12 & $<0.001$ \\
\hline $11<12$ & 43.86 (11.08) & $48.95(5.40)$ & -1.72 & 0.110 \\
\hline $12<13$ & $47.73(7.28)$ & $53.44(3.59)$ & -2.60 & 0.030 \\
\hline
\end{tabular}

Note: * Data: Saccani, Valentini, Pereira (18); NB: Newborn; M: Mean; SD: Standard Deviation.
Figure 1 shows the motor development curve of children born preterm in the present study and at term from the Brazilian standardization study [16], in the first year of age. Variability was observed between the age groups with a progressive increase in motor performance scores with the advancement of age in both groups. For the ages of 9, 10, and 12 months, the growth curves demonstrated greater differences between the preterm acquisitions from the present study and the infants born at term [16]. The motor performance of preterm infants was predominantly below scores of the children born at term.

Figure $\mathbf{1}$ - Preterm and at term infants' motor development curve for AIMS gross motor scores by age group in the first year of life.

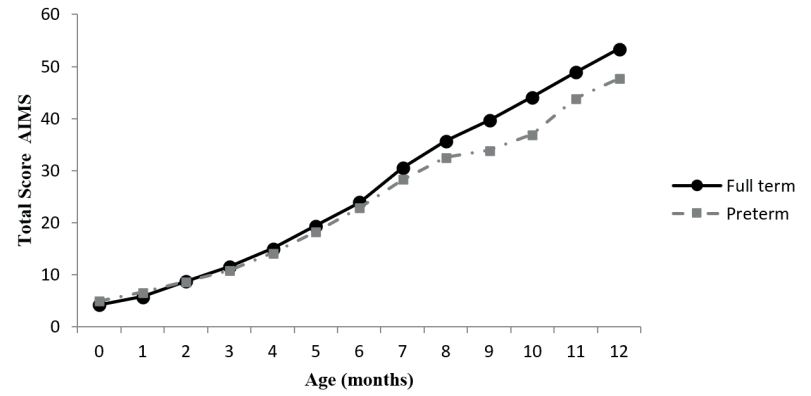

Note: Data for the at term infants by Saccani, Valentini, Pereira [18].

Table 3 displays the values of the percentiles for the assessment of premature infants with AIMS. The values of the percentiles of P1 to P99 indicate the scores for

Table 3 - AIMS motor performance reference scores in Brazilian preterm infants by percentiles and age groups in the first year of life

\begin{tabular}{|c|c|c|c|c|c|c|c|c|c|c|}
\hline \multirow{2}{*}{$\begin{array}{c}\text { Age } \\
\text { Months }\end{array}$} & \multirow{2}{*}{ Min-Max } & \multicolumn{9}{|c|}{ Percentile } \\
\hline & & Pl & P5 & P10 & P25 & P50 & P75 & P90 & P95 & P99 \\
\hline $\mathrm{NB}<1$ & $2-8$ & 2 & 2 & 3 & 4 & 5 & 6 & 7 & 8 & 8 \\
\hline $1<2$ & $2-10$ & 2 & 3 & 4 & 6 & 7 & 8 & 9 & 9 & 10 \\
\hline $2<3$ & $4-15$ & 4 & 5 & 6 & 7 & 9 & 10 & 11 & 12 & 13 \\
\hline $3<4$ & $5-19$ & 5 & 6 & 7 & 9 & 11 & 12 & 14 & 16 & 19 \\
\hline $4<5$ & $6-23$ & 6 & 7 & 9 & 11 & 14 & 17 & 20 & 20 & 23 \\
\hline $5<6$ & $7-36$ & 7 & 9 & 11 & 14 & 18 & 22 & 26 & 28 & 36 \\
\hline $6<7$ & $8-38$ & 8 & 12 & 13 & 17 & 22 & 27 & 31 & 35 & 38 \\
\hline $7<8$ & $13-47$ & 13 & 17 & 20 & 23 & 28 & 32 & 37 & 41 & 47 \\
\hline $8<9$ & $16-50$ & 16 & 16 & 18 & 24 & 34 & 41 & 44 & 46 & 47 \\
\hline $9<10$ & $18-50$ & 20 & 20 & 22 & 26 & 36 & 42 & 44 & 49 & 50 \\
\hline $10<11$ & $25-50$ & 25 & 25 & 25 & 30 & 36 & 45 & 47 & 50 & 50 \\
\hline $11<12$ & $32-54$ & 32 & 32 & 36 & 44 & 50 & 53 & 54 & 54 & 54 \\
\hline $12<13$ & $33-58$ & 33 & 33 & 35 & 42 & 49 & 53 & 57 & 58 & 58 \\
\hline
\end{tabular}

Note: NB: Newborn. 
differentiation of the motor acquisitions at different ages. The data shows that the categorization of typical, suspicious, and atypical children is possible, since the values of the scores differentiate the percentiles (P1 to P99). The lowest differentiation capacity was observed between P1 and P5, at the ages of $0,8,9,10,11$, and 12 months; and between P95 and P99 at 0, 10, 11, and 12 months. In the 1st and 4th month, the 90th and 95th percentiles are not differentiated; and at 10 months, the same happens with percentiles 1 to 10 , as well as at 11 months with percentiles 90 to 99 .

Figure 2 shows the motor development curves of preterm infants, which shows the highest behavioral variation at the $2 \mathrm{nd}$ to 7 th month. At these ages, the values indicate that AIMS distinguishes premature infants in the different percentiles analyzed. The months $0,4,8,9,10$, 11 , and 12 revealed some percentile overlap (P1, P5, and P10; P90, P95, and P99), as described above in Table 2.

Figure 2 - Motor development curve, assessed by AIMS, of children born preterm, according to percentiles and age group up to 12 months of age.

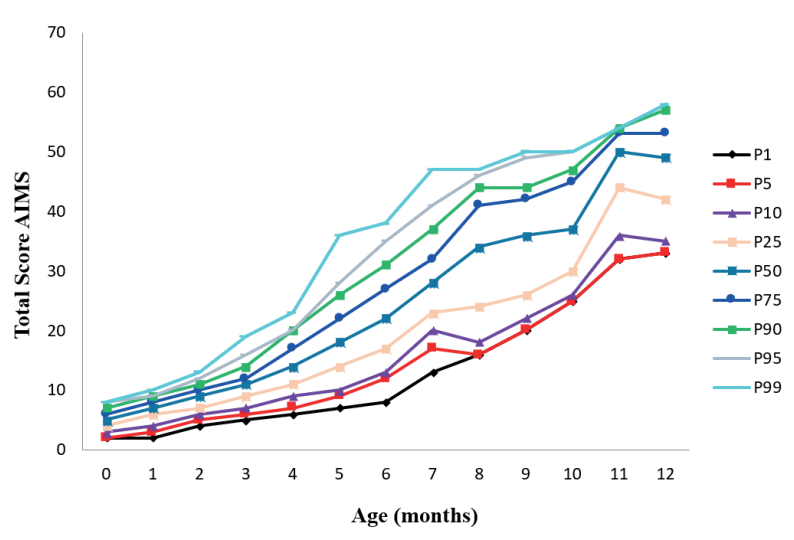

\section{Discussion}

The present study was conducted with children born prematurely in Brazil to determine reference values and categorization of motor performance for the AIMS. The results indicate that preterm children, at the first year of life, present different motor trajectory when compared to those that were born full-term. Considering the norms previously established [18, 20], the AIMS showed a differentiated sensitivity in the performance categorization of preterm infants from the present sample. The results suggest that the normative data presented for premature infants are the most appropriate to interpret the results of the assessment when using the AIMS for that specific population. The differences observed in the age groups between the motor acquisitions of preterm infants and full-term infants were sufficient to indicate the use of different criteria for the determination of the performance.

When comparing the mean scores of the motor performance of children born prematurely with the values from the children born full-term, the preterm infants obtained lower scores in all age levels from two months and beyond. Therefore, preterm infants presented different trajectories than that of full-term children, even with the correction of the gestational age. Previous studies suggest that preterm infants present slower development, with different progression rates and inferior quality in the postural control and antigravitational movements $[2,3,5]$, corroborating the results presented here. The results of the present study help fill the gap detected in the literature of the need for adjustments in the norms for clinical decision making in relation to the preterm newborns [17], providing standards from the percentile 1 to 99 for Brazilian children born preterm.

It's also important to emphasize that although studies using AIMS report similarities between fullterm and preterm infants for some age groups, it was as argument to the potential differences between the children in the acquisition of motor milestones and in the percentiles' progress $[6,15,16]$. The few similarities observed between full-term and preterm groups, in previous studies $[6,15,16]$, seem to occur in samples of preterm infants with over 32 weeks of gestation. Yet, even in these studies, the percentiles and similarities between preterm and full-term infants were restricted to certain age groups $[15,16]$. Therefore, the previous studies reinforce that infants born preterm have less satisfactory results in motor performance tests, particularly if born under 32 weeks of gestation [2, 3]. All these results combined reinforced the importance of the present study. The present sample was composed of preterm infants with gestational ages between 20 and 36 weeks and with a wide range of birth weights (between 580 and 3,800 grams); consequently, motor performance variability was evident, reflecting the reality of the condition of prematurity and establishing the need for specific standards.

Given the results, the present study provides evidence for the existence of specific development and postural acquisitions by premature infants, in a different rhythm than their full-term peers and with variation in the quality of the movements, with developmental trajectory differences observed. Although our results 
cannot be generalized for all preterm infants, we believe that the data reflects a characteristic trajectory for the Brazilian premature population, considering the large sample size and the representativeness of different regions of the country. The percentiles described indicate that by using the curves established in this study, it is possible to differentiate typical and atypical motor behaviors.

Also, when recognizing a different posture trajectory acquisition of preterm and full-term infants using AIMS, we observed that higher scores from preterm infants in the first 2 months, in this case, would most likely be indicating the greater sensitivity of AIMS for the assessment of preterm infants, compared to fullterm in the two first months of life. In other words, the results would not be necessarily demonstrating higher motor performance for preterm infants over full-term infants, but rather, a greater capacity of the AIMS for behavioral differentiation of preterm infants. One plausible explanation is that the number of items of AIMS for assessment at this age range is not sufficient for the evaluation of full-term infants, but more suitable to premature infants. This assertion is reinforced when examining previous studies with AIMS that emphasized the low power of behavioral discrimination of full-term infants in the first 3 months of life [21], probably due to the reduced number of items to evaluate this age group.

Therefore, the results of this study indicate that AIMS is sensitive for the evaluation of at-risk children, such as preterm infants. The reduced number of items to assess the age extremities seems to be enough to measure accurately the motor performance of preterm children. However, due to the lower sensitivity of the scales at the percentiles' extremities (P1 and P5, P95 and P99) it seems limited for full-term infants. This little differentiation between some percentiles does not limit the screening of typical and atypical behaviors, which is observed in the two extremes of the age groups in the study with full-term children [18]. However, this result suggests that for the first month of life for preterm infants AIMS showed no limitation.

Comparing to the previous research of AIMS normative for Brazilian infants [18], the scores of the infants in the present study are lower; for specific ages, the data indicated overlapping in the percentiles 1 to 25 and 25 to 99 . For example, for a newborn there were no differences observed for the percentiles 1 to 25 , where the same score represented the same performance range. Similar occurrence was observed up to the 3 rd month, without differentiation between the 5 th and 10th percentiles. Therefore, it is understood that in the first year of life the AIMS demonstrated to be capable to discriminate, for premature infants, typical motor performance to atypical, with lower sensitivity predominantly for percentiles 1 and 5, 95 and 99. The results also suggested that using AIMS's conventional standards for full-term infants for preterm infants would be inappropriate and would affect clinical decisions about the preterm child.

Another aspect to be discussed that reinforces the importance of using national standards is the updating of the Canadian curves [13]. The data recently presented [13] differ little from the original, being indicated by the authors that the use of standards established for more than 20 years are still recommended for the more recent sample, and that the use of those norms would not affect clinical decisions and research results [11]. However, for a population with cultural, ethnic, and socioeconomic differences such as Brazil, and considering the changes that have passed in the last 20 years in the child care, it all may have had an impact on children's motor assessment. For instance, it can be assumed that the "back to sleep" campaign that started in the 90s interfered with national maternal practices, because many mothers began using the supine posture not only for sleeping but also during the time that the child is awaken and playing, reflecting negatively on the motor acquisitions of children. Specific motor skills seem to appear later in Brazilian infants, influenced by the adoption of supine postures during sleep and its continuity during the day [31]. Future studies are needed to verify the influence of the child's position during sleep, as well as to investigate for how long the child remains in each different position during daily care activities and in games.

Therefore, the importance of this study for the adequate evaluation of premature children was highlighted, since the essential intervention will only be possible through adequate screening. In this research, the percentages described indicate that preterm infants presented lower motor performance than full-term children and that the AIMS has discriminant ability for the clinical evaluation of these children. Thus, the use of the standards determined in this study to evaluate premature infants is recommended, due to the differences in the percentiles when considering fullterm infants' norms and due to the higher discriminative power observed when using the scale. It is recommended that future studies continue to monitor development of preterm infants, using AIMS and maybe associating it 
to other instruments, to specifically differentiate the movements within each posture where the differences are more evident in order to provide task-specific interventions for preterm children.

\section{References}

1. Sampaio TF, Nogueira KPA, Pontes TB, Toledo AM. Comportamento motor de lactentes prematuros de baixo peso e muito baixo peso ao nascer. Fisioter Pesq. 2015;22(3):253-60.

2. Pin TW, Darrer T, Eldridge B, Galea MP. Motor development from 4 to 8 months corrected age in infants born at or less than 29 weeks' gestation. Dev Med Child Neurol. 2009;51(9):739-745.

3. Pin TW, Eldridge B, Galea MP. Motor trajectories from 4 to 18 months corrected age in infants born at less than 30 weeks of gestation. Early Hum Dev. 2010;86(9):573-580.

4. Prins SA, Von Lindern JS, Van Dijk Versteegh FGA. Motor Development of Premature Infants Born between 32 and 34 Weeks. Int J Pediatr. 2010;7:1-4.

5. Nuysink J, van Haastert IC, Eijsermans MJC, KoopmanEsseboom C, Helders PJM, Vries LS. Prediction of gross motor development and independent walking in infants born very preterm using the Test of Infant Motor Performance and the Alberta Infant Motor Scale. Early Hum Dev. 2013 Sep; 89(9):693-7.

6. Retliffe AP, Gherphelli JLD. Differences in walking attainment ages between low-risk preterm and healthy full-term infants. Arq Neuropsiquiatr. 2012;70(8):593-598.

7. Spittle AJ, Lee KJ, Spencer-Smith M, Lorefice LE, Anderson PJ, Doyle LW. Accuracy of Two Motor Assessments during the First Year of Life in Preterm Infants for Predicting Motor Outcome at Preschool Age. PLoS One. 2015;10(5):e0125854.

8. Badr LK, Bookheimer S, Purdy I, Deeb M. Predictors of neurodevelopmental outcome for preterm infants with brain injury: MRI, medical and environmental factors. Early Hum Dev. 2009;85:279-84.
9. Simões RV, Cruz-Lemini M, Bargalló N, Gratacós E, Sanz-Cortés M. Brain metabolite differences in oneyear-old infants born small at term and association with neurodevelopmental outcome. Am J Obstet Gynecol. 2015;213(2):210.e1-210.e11.

10. Simões RV, Muñoz-Moreno E, Cruz-Lemini M, Eixarch E, Bargalló N, Sanz-Cortés M, Gratacós E. Brain metabolite alterations in infants born preterm with intrauterine growth restriction: association with structural changes and neurodevelopmental outcome. Am J Obstet Gynecol. 2017;216(1):62. e1-62.e14.

11. Bosanquet M, Copeland L, Ware R, Boyd R. A systematic review of tests to predict cerebral palsy in young children. Dev Med Child Neurol. 2013;55(5):418-426.

12. Spittle AJ, Doyle LW, Boyd RN. A systematic review of the clinimetric properties of neuromotor assessments for preterm infants during the first year of life. Dev Med Child Neurol. 2008;50:254-66.

13. Darrah J, Bartlett D, Maguire TO, Avison WR, LacazeMasmonteil T. Have infant gross motor abilities changed in 20 years? A re-evaluation of the Alberta Infant Motor Scale normative values. Dev Med Child Neurol. 2014;56(9):877-81.

14. Herrero D, Gonçalves H, Siqueira AAF, Abreu LC. Escalas de desenvolvimento motor em lactentes: Test of Infant Motor Performance e Alberta Infant Motor Scale. Rev Bras Crescimento Desenvolvimento Hum. 2011;21(1):122-132.

15. Maia PC, Silva LP, Oliveira MMC, Cardoso MVLM. Motor development of preterm and term infants - using the Alberta Infant Motor Scale. Acta Paul Enferm. 2011;24(5): 670-5.

16. Borba LS, Saccani R, Valentini NC. Desenvolvimento motor de crianças nascidas pré-termo e a termo avaliadas com a Escala Motora Infantil de Alberta. Temas sobre Desenvolvimento. 2013;19(105):130-5.

17. Formiga CKMF, Linhares MB. (2011). Motor development curve from 0 to 12 months in infants born preterm. Acta Paediatr. 2011;100(3):379-84. 
18. Saccani R, Valentini NC, Pereira KG. New Brazilian developmental curves and reference values for the Alberta infant motor scale. Infant Behav Dev. 2016;45:38-46.

19. De Kegel A, Peersman W, Onderbeke K, Baetens T, Dhooge I, Van Waelvelde H. New reference values must be established for the Alberta Infant Motor Scales for accurate identification of infants at risk for motor developmental delay in Flanders. Child Care Health Dev. 2013;39(2):260-7.

20. Gontijo APB, Castro Magalhaes L, Guerra MQF. Assessing Gross Motor Development of Brazilian Infants. Pediatr Phys Ther. 2014;26(1):48-55.

21. Saccani R, Valentini NC. Reference curves for the Brazilian Alberta Infant Motor Scale: percentiles for clinical description and follow-up over time. J Pediatr (Rio J). 2012 Jan-Feb;88(1):40-7.

22. Syrengelas D, Siahanidou T, Kourlaba G, Kleisiouni P, Bakoula C, Chrousos GP. Standardization of the Alberta infant motor scale in full-term Greek infants: Preliminary results. Early Hum Dev. 2010;86(4):245-9.

23. Syrengelas D, Kalampoki V, Kleisiouni P, Konstantinou D, Siahanidou T. Gross motor development in full-term Greek infants assessed by the Alberta Infant Motor Scale: Reference values and socioeconomic impact. Early Hum Dev. 2014;90(7):353-7.

24. Evensen KA, Skranes J, Brubakk AM, Vik T. Predictive value of early motor evaluation in preterm very low birth weight and term small for gestational age. Early Hum Dev. 2009;85:511-8.

25. Spittle AJ, Boyd RN, Inder TE, Doyle LW. Predicting motor development in very preterm infants at 12 months' corrected age: the role of qualitative magnetic resonance imaging and general movement assessments. Pediatrics. 2009;123(2):512-7. doi: 10.1542/peds.2008-0590.
26. Fuentefria RN, Silveira RC, Prociano RS. Desenvolvimento motor de prematuros avaliados pela Alberta Infant Motor Scale: artigo de revisão sistemática. J Pediatr (Rio J). 2017;93:328-42.

27. Pereira KRG, Valentini, NC, Saccani R. Brazilian Infants' Motor and Cognitive Development: Longitudinal Influence of Risk Factors. Pediatrics International. 2016;58:1297-1306.

28. Miquelote AF, Santos DCC, Caçola PM, Montebelo MI, Gabbard C. Effect of the home environment on motor and cognitive behavior of infants. Inf. Behav. Dev. 2012;35(3):329-34.

29. Valentini, N.C., \& Saccani, R. Brazilian Validation of the Alberta Infant motor Scale. Phys Ther. 2012;92(3):440-7.

30. Rocha SR, Dornelas LF, Magalhães LC. Instrumentos utilizados para avaliação do desenvolvimento de recémnascidos pré-termo no Brasil: revisão da literatura. Cad. Ter. Ocup. UFSCar. 2013;21(1):109-117.

31. Saccani R, Pereira KRG, Muller AB, Valentini NC, Gabbard C. Influence of biological factors and affordances in the home on infant motor development. Pediatr Int. 2013;55(2):197-203. 